ISSN 2745-7168 (DARING)

MUQODDIMA Jurnal Pemikiran dan Riset Sosiologi 2 (1), 2021: 47-62

ARTIKEL

DOI: 10.47776/MJPRS.002.01.04

\title{
Kedatuan Luwu: Nilai-Nilai To Accana Luwu
}

\section{Kedatuan Luwu: the Values of To Accana Luwu}

\author{
Yunus \\ Jurusan Teknik Informatika, Fakultas Teknik, Universitas Pamulang (UNPAM) \\ Email: nurhang542@gmail.com \\ Mukhoyyaroh \\ Jurusan Sastra Inggris, Fakultas Sastra, Universitas Pamulang (UNPAM) \\ Email: mukhoyyaroh2407@gmail.com
}

\begin{abstract}
Abstrak
Penelitian ini bertujuan mengambarkan nilai To Ciung Maccae Ri Luwu. Penelitian mengunakan metode library research dengan memahami buku terkait To Ciung Maccae Ri Luwu. Datu Luwu bernama Datu Etenriawe (15811611), dikenal seorang negarawan dan cendekiawan yang banyakmemberikan perhatian terhadap kondisi kedatuan. Dia bernama Tociung. Tociung banyak memberikan ide-ide atau buah pikiran dan pesan-pesan kepada kedatuan/ pemerintah yang bertujuan untuk memelihara kelangsungan kerajaan, sehingga kedatuan terhindar dari kehancuran. Persatuan bulat telur dimaknai, bahwa segala masalah yang ada di dalam negara atau negeri dihadapi bersama-sama, baik dalam hal keburukan maupun dalam hal kebaikan. Kemudian persatuan bagaikan bulat beras, dimaknai sebagai suatu persatuan yang bersifat vertikal adalah persatuan antara raja atau pemimpin dengan rakyatnya, sehingga apa yang menjadi kebesaran dari sang raja, akan menjadi kekuatan bagi sang hamba. Intergrasi kedelapan sifat-sifat antara seorang pemimpin dengan masyarakatnya, maka akan membentuk persatuan di dalam masyarakat. Negara atau negeri akan kuat, dan tahan terhadap gangguan dari luar. Kemudian persatuan ada beberapa macam menurut pemikiran Maccae ri Luwu, yaitu "bersatu bagaikan telur ayam, bersatu bulat bagaikan beras, dan bersatu bulat bagaikan buluh bambu".
\end{abstract}

Kata Kunci: Datu Etenriawe, nilai, Maccae Ri Luwu 


\begin{abstract}
This study aims to describe the value of To Ciung Maccae Ri Luwu. The research uses library research method by understanding books related to To Ciung Maccae Ri Luwu. Datu Luwu named Datu Etenriawe (1581-1611), known as a statesman and scholar who gave a lot of attention to the condition of kedatuan. His name is Tociung. Tociung gave many ideas or thoughts and messages to the kedatuan/government which aimed to maintain the continuity of the kingdom, so that the kedatuan avoided destruction. The unanimous union is interpreted, that all problems that exist in the country or country are faced together, both in terms of bad and in terms of goodness. Then the union is like a round of rice, interpreted as a vertical union is the union between the king or leader and his people, so that what is the greatness of the king, will become strength for the servant. The integration of the eight characteristics among the leader and the community, would invoke unity in the community. The state or country will be strong, and resistant to outside interference. Then there are several kinds of unity according to Maccae ri Luwu's thought, namely "united like a chicken egg, united like rice, and united like a bamboo reed".
\end{abstract}

Keywords: Datu Etenriawe, values, Maccae Ri Luwu

\title{
Pendahuluan
}

Periode Tomanurung atau periode Lontara (periode sejarah), masyarakat Luwu mengenal zaman I Lagaligo yaitu zaman pemerintahan para dewa dari botinglangi (langit) dan dari peretiwi (dunia Bawah) karena para dewa-dewa yang memerintah di ale kawa (dunia tengah) kembali ke tempatnya masing-masing. Sehingga pada akhir periode Galigo, dikisahkan rakyat tidak mempunyai raja lagi, maka terjadilah kekacauan (chaos) yang disebut dengan masa sianrebale (homo homoni lupus). Mereka hidup dalam kelompok-kelompok dengan kepala kelompok masing-masing yang disebut dengan anang. Antara satu kelompok dengan kelompok yang lain saling bermusuhan dan saling bunuh-membunuh. Zaman ini, oleh Pelras disebut dengan zaman anarkis atau kekacauan. Zaman tersebut berlangsung cukup lama, kurang lebih pitu pariama (mungkin yang dimaksud tujuh generasi atau tujuh puluh tujuh tahun). Selama masa sianrebale, sistem kelembagaan masyarakat Luwu yang disebut anang, macet. Terjadi kekosongan kekuasaan. Ciri masyarakat ini adalah anarkis, tanpa aspirasi, tanpa adat, tanpa hukum, dan tanpa peradilan. Antara satu kelompok dengan kelompok lainnya saling menerkam. Konflik yang berlarut-larut ini menyadarkan bahwa masyarakat Luwu makin jauhnya mereka dari tujuan kemanusiaan. Masyarakat Luwu kemudian sadar akan perlunya menciptakan perdamaian yang kekal di antara masyarakat kaum (anang).

Kondisi masyarakat dalam keadaan kacau dan bercerai berai. Karena itu, mereka mencari tokoh yang dapat mempersatukan masyarakat yang telah berceraiberai dan dalam keadaan kacau (chaos). Melalui pencarian yang panjang, maka ditemukanlah orang yang mereka perlukan yaitu seorang Tomanurung (orang turun) 
(Hadi Mulyono dan Abd Muthalib 1979:15) dan mereka sepakat menjadikannya raja melalui suatu "perjanjian bersama" yaitu antara Tomanurung dengan wakilwakil rakyat. Menurut persfektif masyarakat Luwu, Tomanurung artinya orang yang turun dari langit atau kayangan. Disebut demikian karena umumnya Tomanurung tidak diketahui berita kedatangannya terlebih dahulu, tiba-tiba muncul dan kehadirannya memang sedang ditunggu-tunggu untuk memperbaiki keadaan yang sedang kacau. ${ }^{1}$ Karena itu, Tomanurung bagi masyarakat Luwu dan Bugis-Makassar pada umumnya dianggap sebagai penyelamat, pemersatu dan pelanjut kehidupan kerajaan (Hadimulyono dan Abd Muttalib 1979:15).

Kemampuan dan kharisma yang dimiliki oleh Simpurusiang membawa masyarakat kepada kehidupan yang lebih damai, sehingga oleh masyarakat Luwu, Simpurusiang dianggap sebagai tokoh Tomanurung. Dengan demikian, kalau kita melakukan reinterpretasi secara analitis mengenai Tomanurung, maka Tomanurung (orang yang turun dari tempat yang tinggi) oleh masyarakat BugisMakassar, dimaknai dengan orang yang memiliki pandangan lebih luas dan maju serta menguasai semua aspek-aspek kepemimpinan yang diperlukan masyarakat pada masa itu. Seperti yang disebutkan oleh Andi Anton Pangeran (2006:66), bahwa Tomanurung dianggap sebagai simbol suatu tipe ideal dari kepemimpinan politik (political leadership) dalam budaya politik masyarakat Luwu tradisional. Meskipun mungkin badan-badan pemerintahan yang dibentuk tersebut belum sepenuhnya berfungsi dan mungkin hanya bersifat semu, tapi paling tidak, unsurunsur demokrasi sudah lahir.

Konsepsi pembentukan pemerintahan dengan konsep Tomanurung, menggambarkan kehadiran tokoh pembentukan kedatuan (kerajaan) secara religius magis dengan tokohnya Simpurusiang. Datu Luwu ini diriwayatkan menikah dengan seorang putri yang bernama Patiangjala, yang bergelar Toppoe ri Busa Empong, dianggap sebagai putri Sawerigading dan We Cudai, pasangan yang telah diturunkan ke dunia tengah selama tujuh generasi. Kisah sakral ini, sesungguhnya juga masih merupakan proses legitimasi atas tokoh yang berhasil mengakhiri proses chaos. Itulah sebabnya kehadiran dan tampilannya menjadi pemimpin yang disakralkan, akan tetapi bersifat profan dalam kedudukan kekuasaannya. Dan itupulah sebabnya kepadanya diemban tugas untuk melindungi segenap kaum dan memelihara keluhuran Tana Luwu dengan tidak mengambil harta rakyatnya kecuali yang wajib diberikan untuk kepentingan pemerintahan (Mattulada 1998:29). Merujuk kepada teori pembentukan Negara, ${ }^{2}$

1 Kerajaan-kerajaan Bugis-Makassar pada umumnya masing-masing mempunyai tokoh Tomanurung, seperti Kerajaan Luwu dengan tokoh Simpurusiang, Kerajaan Gowa tokoh tomanurungnya adalah seorang putri (raja putri) dan tomanurung di Kerajaan Bone bernama Matasilompo' $E$, tokoh tomanurung, seperti juga dengan makhluk-makhluk lainnya yang berasal dari dunia atas, dianggap oleh masyakat Bugis-Makassar, memiliki berapa karakteristik yang membedakannya dengan manusia yang berasal dari bumi. Tomanurung dianggap memiliki kekuatan "supranatural" dan diperlengkapi pula dengan benda keramat yang mempunyai daya kemampuan yang melebihi benda hasil ciptaan manusia biasa di bumi.

2 Kata monarki berasal dari bahas Latin, monarchia yang artinya the rule of one. Pengertian monarki tersebut bermakna peraturan atau penguasaan oleh satu orang yang juga memegang 
bahwa pada masa paling awal, bentuk negara kaum adalah monarki. Dalam sistem ini pergantian dan perubahan pemegang kedaulatan berlangsung menurut garis keturunan.

Pada masa klasik Hindu/Budha, kemauan politik (polical will) aristokrat seperti itu memang sudah tampak dalam bentuk aturan hukum, lembaga peradilan, dan pejabat yang mengawasi pelaksanaan konstitusi, seperti ditemukan pada prasasti yang berkaitan dengan penetapan sima (Slamet Muljana 1967). Akan tetapi infrastruktur hukum pada prasasti terkesan masih bertendensi memperkuat legitimasi raja dari pada melindungi rakyat atau dengan kata lain belum hilang perlakuan diskriminatif terhadap rakyat. Raja adalah wakil dewa, sehingga raja masih dianggap tidak dapat berbuat salah dan titah raja dianggap setara dengan hukum. Pada periode datu ke-12 We Tenrirawe (1581-1611), terjadi perubahan besar dalam sistem pemerintahan Kedatuan Luwu.

Masa Tomanurung pertama sampai datu Luwu ke-11 Datu Maningoe Ri Bajo (1551-1581), badan pemerintahan Pakkatenni Ade' dan Ade'Asera tidak banyak berfungsi atau dengan kata lain pemerintahan yang dibangun di atas landasan demokrasi belum berjalan secara maksimal; dimana kebijakan pemerintah (raja) belum sepenuhnya memberi keberpihakan pada rakyat, pemerintah belum sepenuhnya memberikan perlindungan kepada rakyatnya, dan atau rakyat belum mendapat hak yang pantas dari raja, sampai datangnya periode Datu ke-12 yang bernama We Tenrirawe (1581-1611).

Berdasarkan konstitusi pemerintahan Kedatuan Luwu sebagaimana yang telah disebutkan di atas, maka penulis berkesimpulan, bahwa pada zaman pemerintahan Datu We Tenrirawe (1581-1611), Kedatuan Luwu mengalami suatu revolusi. Datu We Tenrirawe sebagai seorang datu perempuan, berhasil melakukan revolusi membawa Kedatuan Luwu menjadi negara (state) yang sebelumnya bersifat monarki parlemen meningkat menjadi pemerintahan yang bersifat monarki konstitusional. ${ }^{3}$

Datu perempuan ini sebagai sebuah revolusi, karena pemerintahan lahir dan dibangun dengan landasan demokrasi yang ditandai dengan adanya perjanjian

kedaulatan tertinggi. Secara bebas monarki kadang-kadang diterjemakhan kerajaan, kekaisaran, kesultanan atau raja, kaisar dan sultan saja. H. Sitanggang, Filasafat dan Etika Pemerintahan, (Jakarta: Pustaka Sinar Harapan, 1998), 132.

3 H.Sitanggang membagi perkembangan monarki ke dalam tiga sistem; 1) Monarki absolut, ialah sistem kerajaan yang seluruh kekuasaan pemerintahan berada ditangan raja. Pengaturan yang dilakukan oleh raja dengan sistem ini lebih bersifat keinginan sendiri dari pada menjalankan pemerintahan. Tidak ada aturan atau kekuasaan yang dapat membatasi kekuasaannya, 2) Monarki parlementer ialah bentuk pemerintahan kerajaan yang pelaksanaan kekuasaan tidak dipertanggung jawabkan kepada raja, tetapi mentri-mentri yang bertanggung jawab kepada parlemen. Dalam sistem monarki parlementer, raja hanya bersifat simbol kebanggaan bersama atas nilai-nilai sejarah bangsa yang antara lain dikenal dengan istilah "raja tidak dapat berbuat salah 3) Monarki konstitusi merupakan bentuk lanjutan dari monarki parlementer. Dengan sistem ini kekuasaan raja telah punya batas; segala sesuatu harus mengikuti ketentuan hukum. Raja hanya boleh berbuat apa yang perbolehkan oleh hukum.. Dengan demikian, jika teori di atas dihubungkan dengan perkembangan Kedatuan Luwu, maka periode Galigo menjalankan sistem pemerintahannya bersifat monarki absolut, periode Simpurusiang sampai Maningo ri Bajo (1551-1581) dengan sistem pemerintahan monarki parlementer dan periode Datu Etenriawe (1581-1611) menjalankan pemerintahan dengan sistem monarki konstitute. Monarki konstitute adalah bentuk kerajaan yang kekuasaan rajanya dibatasi oleh ketentuan-ketentuan dan atau undang-undang dasar. 
kerja sama antara Tomanurung (Simpurusiang) dan wakil-wakil rakyat. Namun, merujuk kepada bunyi dasar-dasar hukum atau undang-undang pemerintahan tersebut di atas, maka jelaslah bahwa sebelum Datu Etenriawe (1581-1611), demokrasi belum berjalan sepenuhnya, atau dengan kata lain pemerintahan masih bercorak monarki parlementer, di mana masih melekat anggapan "raja tidak dapat berbuat salah," sehingga dengan image seperti itu, maka masih memberi peluang kepada pihak kerajaan untuk memperlakukan rakyat secara sewenang-wenang dan tidak melibatkan rakyat dalam pemerintahan.

Masa Datu Etenriawe (1581-1611), yang mau tidak mau, pihak kerajaan harus bekerja keras untuk melakukan suatu perubahan yang dapat dirasakan secara langsung olek rakyat. Penulis menduga, bahwa inilah yang melatar belakangi, lahirlahnya konstitusi baru Kedatuan Luwu, seperti yang disebutkan di atas. Pada masa Datu Etenriawe (1581-1611), dikenal seorang negarawan dan cendekiawan yang banyak memberikan perhatian terhadap kondisi kedatuan. Dia bernama Tociung. Tociung banyak memberikan ide-ide atau buah pikiran dan pesan-pesan kepada kedatuan/pemerintah yang bertujuan untuk memelihara kelangsungan kerajaan, sehingga kedatuan terhindar dari kehancuran.

Berdasarkan buah pikiran dan pesan-pesan dari Tociung, maka lahirlah hukum dasar pemerintahan Kedatuan Luwu yang berpihak kepada rakyat. Menurut Tociung, agar kerajaan dapat bertahan dan hidup terus, maka kedatuan harus pandai menyesuaikan diri dengan perubahan-perubahan yang telah menjadi kenyataan; kedatuan harus menyesuaikan diri dengan aspirasi rakyat, untuk itu, perlu diadakan perubahan-perubahan dalam kedatuan. Ide-ide dan pemikiran Tociung ${ }^{4}$ sangat membantu pemerintahan zaman Datu We Tenrirawe, karena itulah Tociung mendapat gelar "To Accana Luwu" (cendekiawan Luwu).

Kerajaan Luwu merupakan kerajaan tertua di Sulawesi Selatan (Ima Kusuma 2006:304), bahkan dipandang sebagai asal-usul raja-raja di Sulawesi Selatan. Hal ini dibuktikan dengan adanya penghargaan terhadap kaum bangsawan Luwu. Disamping itu hadirnya artefak berupa istana yang merupakan realita kekinian Kerajaan Luwu yang berada tepat di sentral Kota Palopo. Bahkan Kern dalam Abidin menyatakan, bahwa Kedatuan Luwu merupakan kerajaan maritim terbesar yang sering mengirimkan anak-anak bangsawannya untuk pergi berlayar sampai

$4 \quad$ Ide-ide dan pemikiran Tociung (To Accana Luwu), untuk waktu yang lama telah menjadi pedoman kehidupan manusia dan masyarakat di Kedatuan Luwu. Pemikirannya bahka menembus jauh ke daerah-daerah sekitarnya, antara lain ke Kerajaan Soppeng (salah satu Kerajaan Bugis). Pemikiran To Accana Luwu ini dipelajari, dikaji, dihayati dan disyaratkan untuk terwujud dalam praktek kehidupan terutama oleh raja dan kaum bangsawan Luwu dan Soppeng. Seorang raja Soppeng yang bernama La Basok To Akkarangeng (Datu Soppeng ke-9), sebelum dilantik menjadi raja Soppeng, Secara khusus melakukan perjalanan berkunjung ke Tanah Luwu, ke kediaman To Accana Luwu, guna memperoleh bekal yang berupa pengajaran dan pendidikan mengenai berbagai aspek dalam kehidupan, terutama dalam hal pengaturan masyarakat dan kerajaan. Pemikiran To Accana Luwu seperti yang diturunkan kepada La Basok, sangat besar pengaruhnya, mempedomani berbagai aktivitas kehidupan kenegaraan dan kemasyarakatan di Kerajaan Soppeng. Pengetahuan To Accana Luwu mengenai keadaan masyarakat dan karakter manusia Luwu serta keadaan masyarakat dan karakter manusia Soppeng beserta lingkugan alam dan lingkungan sosialnya, menyebabkan pemikiran itu menjadi relevan sebagai pegangan dalam pengaturan Negara dan masyarakat. Dengan demikian Pemikiran To Accana Luwu telah menembus batas-batas wilayah kerajaan tempat To Accana melakoni kehidupannya. 
ke negeri asing (Abidin 1999).

Kebesaran Kedatuan Luwu sudah pernah dipublikasikan oleh seorang pujangga Keraton Majapahit pada karya kesusastraannya yang termasyhur "Negarakertagama" yang ditulis pada tahun 1365 (Pegeaud 1960), yang menyebutkan Luwu sebagai sebuah negeri (Yamin 1948; Mattulada 1995). Sumber ini dianggap sebagai sumber tua tentang Luwu. Semua tempat yang disebutkan dalam sumber Jawa kuno tersebut, seperti Bantaeng, Luwu, Makassar, dan Selayar dapat diidentifikasikan terletak di Sulawesi Selatan, dan Luwu merupakan satusatunya Kerajaan Bugis yang populer dengan sebutan “Kedatuan Luwu." Deretan catatan sejarah kebesaran Luwu, yang bahkan dipandang sebagai the best actor bagi kerajaan-kerajaan Bugis-Makassar melalui I La Galigo, Kedatuan ini juga menampilkan sejarah yang menarik pada zaman Lontara atau zaman Tomanurung, yaitu sebuah pemerintahan yang dapat dikategorikan pemerintahan demokratis.

\section{Kedatuan Luwu dalam Sejarah}

Pemerintahan Kedatuan Luwu, wilayah kekuasaannya sangat luas, sehingga secara garis besar wilayah kekuasaan Kedatuan Luwu dibagi atas 3 yang masing-masing dipimpin oleh seorang pemimpin yang disebut dengan $M a^{\prime}$ dika Ponrang, Ma'dika Bua, dan Makole Baebunta. Mereka merupakan perpanjangan tangan dari pajung dalam menjalankan pemerintahannya di daerah-daerah. Ketiga pemimpin tersebut dikenal dengan istilah ade telluE. Untuk lebih jelasnya struktur pemerintahan Kerajaan Luwu pada masa dahulu dapat dilihat pada bagan di bawah ini: Datu/Pajung, Kadi, Pakkateni Ade'

Struktur di atas, pajung dalam menjalankan pemerintahannya di dalam istana dibantu oleh pakkatenni (Opu Patunru, Opu Pabbicara, Opu Tomarilaleng, dan Opu Balirante). Dalam pemungutan suara, keempat jabatan orang tersebut dianggap satu suara, karena keempat jabatan tersebut dianggap satu kesatuan dalam suatu sistem pemerintahan Kedatuan Luwu. Mereka tidak bisa terpecah dalam bersuara. Hal ini menunjukkan bahwa jauh sebelumnya sistem kepemimpinan lokal, khususnya di Luwu sudah mengenal nilai-nilai demokrasi yang semestinya sampai saat ini dapat diterapkan dan tidak harus mencontoh sistem demokrasi dari negara barat, sebab kita telah memiliki modal politik yang sesuai dengan budaya masyarakat pendukungnya.

Terkait dengan pajung yang dianggap sebagai seorang pemimpin yang harus bisa mensejahterakan masyarakatnya dan harus bisa menjadi seorang pajung atau raja yang tangguh yang bisa menjadi pelindung dan pengayom, masyarakat. Maka dari itu dalam proses pengangkatan pajung diwajibkan melewati proses pengujian sebelum dilantik menjadi pajung ${ }^{5}$

Proses sebelum dilantik menjadi pajung, yaitu seorang datu harus tinggal di atas panggung kecil yang tinggi tanpa atap, selama sembilan hari sembilan malam. Selama berada di panggung kecil itu, calon pajung hanya diberi minuman sedikit

$5 \quad$ Pada sistem pemerintahan Kedatuan Luwu, seorang yang akan diangkat menjadi pajung masih bergelar datu, dan setelah dilantik maka ia boleh memakai gelar pajung, namun ketika berkomunikasi dengan seseorang, maka ia tetap disapa atau dipanggil datu. 
dan tidak diberi bantal. Hal ini bertujuan agar seorang raja/pajung bisa merasakan penderitaan rakyat yang kekurangan makanan dan tinggal dalam rumah yang sempit tanpa atap. Setelah lulus ujian, maka seorang pajung diwajibkan belajar hukum adat dan sistem kepemimpinan, serta etika.

Proses pengangkatan seorang pajung atau raja pada Kedatuan Luwu memperlihatkan bahwa seorang pemimpin harus bisa merasakan apa yang dirasakan oleh rakyatnya. Bukan sekedar raja yang bisa berkuasa dan semena-mena terhadap rakyat. Pajung dimaknai sebagai payung yang bisa dijadikan sebagai tempat berlindung (Rahman dan Nurhayati 2003:397). Hal ini juga disebutkan dalam naskah I La Galigo, bahwa Sawerigading sebelum menjadi pajung di Kedatuan Luwu dianjurkan untuk pergi mengembara untuk belajar teknologi serta polapola kepemimpinan semua raja-raja yang ada di muka bumi ini (Fauziah 2001:67). Dengan harapan seorang pajung harus bisa menguasai aspek kepemimpinan, yang dalam ungkapan bahasa Bugis disebut nalliburi sulapa eppa'e, artinya segala segi kehidupan harus dikuasai oleh seorang pajung atau pemimpin.

Seorang pajung dalam sistem kedatuan Luwu harus maddara takku (berdarah putih). Yakni seorang bangsawan murni yang dimaknai sebagai seorang yang memiliki hati yang suci dan murni, bebas dari godaan materi yang bersifat duniawi. Pada sistem kepemimpinan Kedatuan Luwu, dianggap bahwa pajung atau raja yang memiliki hati yang bersih dan batin yang bersih, maka ia mampu mengendalikan diri. Seorang pajung atau raja harus mampu mempersatukan semua aspirasi yang ada dalam masyarakat, yakni mempersatukan aspirasi dari atas dan dari bawah. Hal ini tertuang dalam ungkapan Bugis, bahwa massorong pawo mangngelle wae pasang artinya mengalir dari atas seperti air sungai dan berkembang dari bawah seperti air pasang.

Sistem pemerintahan kedatuan Luwu dikenal dengan ade seppulo dua, yaitu satu suara datu, 1 suara pakkatenni ade, 1 suara kadi dan 9 suara ade asera. Kemudian diasosiasikan dalam budaya Luwu, bahwa angka yang paling tertinggi adalah 12 (seppulo duo) dianggap sebagai angka yang paling sempurna. Ade asera terdiri atas 9 (Sembilan) jabatan dan orang, yang masing-masing dibagi tiga, yakni (1) bête-bete tellu terdiri atas Matowa Wage, Matowa Cendrana, Matowa Lalantonra, (2) Anak Tellue yang terdiri atas; Makole Baebunta, Madika buah, Maddika Ponrang, (3) Bendera Tellu terdiri atas: goncingnge, macangnge, kamummue (Iriani 2011:15)

Kadi merupakan perangkat agama yang membawahi Khatib dan Bilal, dia bertugas mengurus segala sesuatu yang berkaitan dengan agama Islam. Kehadiran Kadi dalam struktur pemerintahan Kerajaan Luwu menunjukkan, bahwa Islam pada masa itu merupakan spirit Kedatuan Luwu, bahkan segala mekanisme yang dijalankan di Kerajaan Luwu pada saat itu tidak terlepas dari kontrol ajaran Islam. Tugas dari ade seppulo dua adalah sebagai pengambil keputusan dalam pemerintahan Kerajaan Luwu pada masa lampau. Masing-masing perangkat adat tersebut memiliki satu hak suara, termasuk raja (pajung), serta pakkateni ade memiliki satu suara, walaupun diwakili oleh empat orang.

Menurut Setiadi (2011:280) kepemimpinan merupakan kemampuan dari seseorang untuk mempengaruhi orang lain, yaitu yang dipimpinnya, 
sehingga orang yang dipimpinnya bertingkah laku sesuai yang dikehendaki oleh pemimpinnya. Kemudian sistem kepemimpinan ada dua macam ada yang resmi dan ada yang tidak resmi. Kepemimpinan resmi selalu tersimpul dengan jabatan, sementara kepemimpinan tidak resmi didasarkan pada pengakuan dan kepercayaan masyarakat. Apabila disimak kedua sistem kepemimpinan yang diuraikan di atas, maka sistem kepemimpinan yang dimaksud dalam tulisan ini adalah sistem kepemimpinan tidak resmi. Raja atau pajung memimpin berdasarkan kepercayaan masyarakat, yang sangat terkait dengan istilah To Manurung. Bahkan Errington dalam Gibson menyatakan bahwa jabatan pada masa Kerajaan Luwu di turunkan ke kandidat berdarah paling murni (Gibson 2009:223).

Pemimpin atau raja dalam masyarakat Bugis, seperti di Kedatuan Luwu selalu dikaitkan dengan adanya mitos To Manurung, yaitu orang yang turun dari langit. Sehingga pajung atau datu dianggap sebagai dewa yang turun dari kayangan yang diutus oleh Tuhan untuk memerintah di muka bumi. Secara etimologi "To Manurung" berasal dari kata To yang berarti orang dan kata Manurung berarti turun. Jadi To Manurung secara harfiah berarti orang yang datang dari luar, dari tempat yang tinggi. Oleh karena itu raja atau pajung pada Kedatuan Luwu dianggap sebagai pemimpin yang sempurna yang mampu menguasai semua aspek-aspek kepemimpinan yang dibutuhkan oleh masyarakat.

Sifat ideal seorang pemimpin dalam sistem kepemimpinan Kedatuan Luwu yang menjadikan To Manurung sebagai simbol budaya politik pada sistem kepemimpinan tradisional Luwu. Oleh karena itu segala yang menyangkut tata kelakuan yang dilakukan oleh Sawerigading diusahakan menjadi pola tata kelakuan bagi orang Luwu.

Seorang pajung atau raja dalam menjalankan sistem pemerintahannya, mengalami perubahan, yakni sorang pajung atau raja biasanya mengalami pertambahan sifat-sifat To Manurungnya, oleh karena itu dievaluasi oleh seorang boto atau lebih dikenal dengan Maccae ri Luwu. Apabila seorang raja tidak mendengar atau menghiraukan wejangan seorang boto, maka dia dianggap kehilangan sifat To Manurungnya, dengan demikian seorang raja kehilangan legitimasi politiknya sebagai seorang raja dan dewan adat akan memaksa seorang raja meletakkan jabatannya dengan istilah ri sorong rakko lopinna artinya perahunya didorong turun ke laut dalam keadaan air pasang surut.

Boto merupakan orang yang berada di luar istana dan tidak terikat dengan struktur yang ada di istana. Namun pemikiran-pemikirannya melampaui ruang dan waktu, serta sangat obyektif. Oleh karena itu seorang boto menjadi panutan di dalam masyarakat juga sebagai tempat bertanya oleh masyarakat dan juga raja atau pajung. Seperti halnya boto yang dijadikan sebagai tempat bertanya oleh banyak orang termasuk raja atau pajung yang bernama To Ciung Maccae ri Luwu. Kemudian lebih dikenal dengan Maccae ri Luwu. Pemikiran-pemikiran Maccae ri Luwulah diikuti oleh Datu Luwu di dalam menjalankan pemerintahannya (Mas'ud 2000: 69).

Tata kelakuan yang dilakukan oleh Sawerigading diusahakan menjadi pola tata kelakuan bagi orang Luwu. Sebagai pajung Tana Luwu, maka ia tidak akan 
mengambil apa-apa dari rakyatnya, kecuali yang diberikan untuk keperluan Tana Luwu. Menurut keterangan dari beberapa informan, bahwa pada masa dahulu, ketika pajung atau datu selesai menjadi pajung atau selesai tugas kedatuannya atau berakhir masa kedatuannya, tidak pernah memiliki harta melebihi hartanya sebelum ia menjabat sebagai pajung, maka ia dianggap sebagai pajung atau datu yang mampu mempertahankan kemuliaan tana Luwu.

\section{Nilai-nilai dalam Pemikiran Maccae ri Luwu}

Penerapan nilai To Ciung Maccae Ri Luwu harus mampu ditunjukan oleh para pejabat berdasarkan nilai-nilai dasar yang dianut oleh daerah. Pandangan tersebut bahwa dalam pemerintahan masih merupakan isu yang sangat vital, mengingat munculnya berbagai permasalahan dalam tata kelola pemerintahan cenderung diakibatkan dari kebobrokan dan rendahnya penerapan nilai-nilai seperti adele' (adil), lempu' (jujur), getteng (teguh).

Menurut Ibrahim ada beberapa pemikiran-pemikiran yang dijalankan oleh Raja Luwu di dalam menjalankan pemerintahannya. Sehingga Kerajaan Luwu pada zaman dahulu menjadi sutu kerajaan yang sangat besar dan berjaya. Adapun pemikiran-pemikiran Maccae ri Luwu dapat dilihat pada penjelasan berikut ini:

\section{Hati nurani}

Maccae ri Luwu menekankan, bahwa hati yang bersih yang dimiliki oleh seorang raja (datu), para bangsawan, pemangku adat dan seluruh masyarakat akan berhubungan sangat erat dengan perilakunya. Oleh karena itu mereka harus memiliki hati yang bening (ati macinnong). Hati nurani yang berada dalam diri manusia merupakan hakekat manusia yang sebenarnya, mata telinga, hidung dan anggota-anggota tubuh lainnya hanyalah menumpang dalam diri manusia. Hatilah yang menggerakkan seluruh anggota tubuh manusia. Oleh karena itu maka segala sesuatu yang ingin dilakukan oleh manusia selalu berdialog dengan hati. Demikian halnya dengan seorang raja dan penegak hukum sebelum memutuskan sesuatu harus mendengar hati nurani.

Terkait dengan hati yang bersih (ati macinnong) maka pada dasarnya pemikiran Maccae ri Luwu menekankan nilai-nilai, ada tongeng, lempu (jujur), dan getteng (teguh). Adapun yang dimaksud dengan ada tongeng artinya perkataan yang benar. Antara perkataan dan perbuatan selalu sama. Ada tongeng harus dimiliki oleh seorang pemimpin pada zaman itu.

Ada tongeng merupakan perkataan yang baik dan benar, dalam hal ini seorang raja harus memiliki nilai tersebut, sehingga apa bila ia berkata, maka katakatanya adalah benar dan selalu terkait dengan hati yang bersih. Antara kata dan perbuatan selalu sama atau dikenal dengan taro ada taro gau.

Nilai lempuk merupakan nilai kejujuran atau dalam bahasa Indonesia berarti lurus, tidak bengkok. Orang yang lurus sangat diperlukan dalam memimpin suatu negara atau masyarakat. Nilai inilah yang dimiliki oleh seorang raja/pajung pada masa Kedatuan Luwu, sehingga masyarakatnya aman dan makmur.

Lempu merupakan kejujuran, sangat penting dimiliki oleh pemimpin pada 
saat ini, sebab nilai lempu sangat jarang dimiliki oleh pemimpin saat ini. Padahal kejujuran adalah kunci dari segala perbuatan manusia. Apabila seorang pemimpin memiliki sifat jujur, maka masyarakatnya akan sejahtera, sebab segala kebijakankebijakan yang dibuat didasari dengan kejujuran.

Getteng adalah sifat tegas dari seseorang, dalam hal ini tidak mudah terpengaruh dan goyah, tetap pada pendiriannya atau bersifat konsisten. Sifat ini merupakan salah satu sifat yang dimiliki oleh seorang datu atau raja pada masa lampau di Kedatuan Luwu. Apabila sifat ini tidak dimiliki oleh seorang pemimpin maka, masyarakat yang dipimpinnya akan terombang-ambing.

Nilai-nilai tersebut sangat penting diterapkan pada kondisi saat ini dan perlu dimiliki oleh seorang pemimpin pada saat ini. Sebab dapat dikatakan, sebagian besar pemimpin tidak memiliki nilai ada tongeng, oleh karena itu lain yang diucapkan lain pula yang dilakukan. Misalnya saja seorang anggota DPR, ketika masih kampanye mereka menjanjikan akan mensejahterakan rakyat, namun setelah menjabat sebagai anggota DPR mereka lupa dengan janji-janjinya itu. Demikian juga program-program yang tidak membolehkan korupsi, namun kenyataannya berbeda. Banyak para pemimpin masuk bui gara-gara korupsi uang rakyat. Hal ini sangat bertentangan dengan nilai ada tongeng yang diterapkan oleh pemimpin di masa Kedatuan Luwu.

\section{Perilaku Manusia}

Perilaku manusia sangat terkait dengan hati nuraninya, segala perilaku yang baik muncul dari hati nurani yang bersih. Seorang pemimpin atau raja harus menjaga perilakunya. Raja yang mempunyai perilaku yang baik otomatis memiliki hati yang bersih dan bisa menempatkan sesuatu pada tempatnya, mampu memelihara perkataan yang benar dan melakukan perbuatan yang bermanfaat untuk manusia atau rakyatnya.

Seorang raja harus mampu menunjukkan nilai keteguhan/ketegasan dan kejujuran yang dibuktikan dengan perbuatan. Hal inilah yang diterapkan dalam menjalankan sistem pemerintahan di Kerajaan Luwu pada masa lampau, sehingga ia menjadi sebuah kerajaan yang besar dan terkenal sampai ke semenanjung Malaysia (Abidin 1999: 54). Sifat-sifat semacam inilah yang semestinya dimiliki oleh setiap pemimpin pada saat ini agar masyarakat bisa tentram damai dan sejahtera.

\section{Penegakan Supremasi Hukum}

Penegakan hukum merupakan suatu yang sangat penting, karena sangat terkait dengan kesejahteraan dan kedamaian di dalam masyarakat. Oleh karena itu maka pada masa pemerintahan Kedatuan Luwu, seorang raja atau pajung sangat mengutamakan adanya supremasi hukum dengan menempatkan sesuatu pada tempatnya (asitinajang).

Penegakan hukum, Maccae ri Luwu menganjurkan agar berhati-hati menghadapi empat jenis manusia dan perlu ripagettengi beccik atau dibentangkan tali pelurus yang tegas. Adapun orang-orang yang dimaksud yaitu: to 
mawatangngE (orang yang memiliki kekuatan dan kekuasaan), to majekkoE (orang culas), to maccaE (orang pandai), to benngoE (orang dungu). Keempat orang tersebut akan mempengaruhi penegakan hukum dalam suatu pemerintahan atau masyarakat. Orang yang memiliki kekuasaan dan kekuatan akan menggunakan kekuasaannya untuk melakukan tekanan pada penegak hukum. Orang yang culas akan memutarbalikkan fakta dan kesaksian, orang pintar akan dapat menyusun argumentasi dan pembenaran atas perbuatan yang salah, kemudian orang dungu akan menimbulkan rasa kasihan dan pada akhirnya prinsip asitinajang atau kewajaran akan ditinggalkan.

Pemikiran Maccae ri Luwu tersebut sangat penting diterapkan pada kondisi saat ini. Masyarakat bingung mencari keadilan, karena tidak ada supremasi hukum. Para penegak hukum tidak memiliki nilai-nilai yang ada dalam pemikiran Maccae ri Luwu seperti yang dungkapkan di atas. Ada tebang pilih dalam penegakan hukum, uang dan kekuasaan bisa mengalahkan keadilan dalam penegakan hukum. Sehingga apabila orang miskin atau tidak mampu melakukan pelanggaran hukum dijatuhi hukuman seberat-beratnya. Sementara orang kaya atau penguasa yang melanggar hukum tidak dihukum karena bisa mempengaruhi hakim atau penegak hukum dengan kekuasaannya atau uang yang dimilikinya.

\section{Persatuan}

"Bersatu kita teguh bercerai kita runtuh" merupakan suatu ungkapan yang digunakan untuk mempersatukan masyarakat. Untuk membentuk suatu masyarakat yang kuat, maka perlu ada persatuan di dalam masyarakat. Menurut Ibrahim (2002) Maccae ri Luwu mengungkapkan beberapa pemikirannya tentang pentingnya persatuan, sehingga ada beberapa sifat yang harus dipelihara untuk menciptakan persatuan, yakni:

1. Seia-sekata mereka di dalam negeri (massituruk-i rilalempanuwa)

2. Jujur mereka kepada sesamanya (sialempurenngi)

3. Saling berkata benar di antara mereka (siakkeda-tengengenngi)

4. Saling memelihara sirik (siasirik-i)

5. Dalam duka mereka bersatu, dalam suka mereka bersatu (jaknauru, deceng nauruk)

6. Ke gunung sama mendaki, tidak saling menurunkan ke lembah, (sitereng ribuluk-E, tessinoreng ri lompok-E)

7. Tidak saling berhitung-hitung di antara sesamanya (tessicirinnainngi ri silasanae)

8. Saling membenarkan apa adanya (sipattongenngi ri akkunae)

Integrasi kedelapan sifat-sifat tersebut pada seorang pemimpin dengan masyarakatnya, maka akan terjalin persatuan di dalam masyarakat. Negara atau negeri akan kuat, dan tahan terhadap gangguan dari luar. Kemudian persatuan ada beberapa macam menurut pemikiran Maccae ri Luwu, yaitu "bersatu bagaikan telur ayam, bersatu bulat bagaikan beras, dan bersatu bulat bagaikan buluh bambu".

Masyarakat Luwu dengan konsep patedunggi, yaitu suatu sikap yang 
bertujuan untuk membuat orang lain suka atau merasa nyaman dan aman tinggal di Kota Palopo. Beberapa sikap yang biasa diimplementasikan oleh masyarakat Luwu, antara lain; ramah kepada siapapun, suka menolong, bersikap sesuai dengan norma dan tata kerama yang telah ditentukan-didasarkan pada pedoman dalam etika kehidupan sehari-hari yang disusun sangat pendek namun memiliki makna yang sangat bermanfaat, yaitu; tidak sombong dengan sifat maegettengpi ${ }^{6}$ serta selalu berusaha untuk mengoreksi diri sendiri. Karena kedamaian merupakan landasan dan pedoman yang dianut dalam berperilaku bagi masyarakat Luwu. Ada berbagai sumber yang mengandung nilai-nilai kedamaian seperti Abbulo Sibatang.

Persatuan bulat telur dimaknai, bahwa segala masalah yang ada di dalam negara atau negeri dihadapi bersama-sama, baik dalam hal keburukan maupun dalam hal kebaikan. Kemudian persatuan bagaikan bulat beras, dimaknai sebagai suatu persatuan yang bersifat vertikal adalah persatuan antara raja atau pemimpin dengan rakyatnya, sehingga apa yang menjadi kebesaran dari sang raja, akan menjadi kekuatan bagi sang hamba. Tidak ada saling mencurigai antara raja dengan rakyatnya, rakyat tidak menginginkan kedudukan raja, demikian juga sang raja tidak ingin diperhambakan oleh rakyatnya. Tidak ada saling memarahi dan saling dendam. Hubungan baik antara raja atau pemimpin dengan rakyat berjalan sampai pada anak cucu. Kemudian persatuan bulat bagaikan buluh bambu, yakni antara raja atau pemimpin dengan rakyatnya bersatu dalam suka maupun duka. Sehingga apabila salah satunya khilaf maka saling mengingatkan, apabila jatuh, maka saling membangkitkan. Persatuan ini merupakan persatuan buluh bambu antara bulat di luar dengan di dalam sama, sehingga apabila rusak di luar, maka rusak pulalah di dalam.

Pemikiran Maccae ri Luwu yang telah dijelaskan di atas menujukkan, bahwa di Sulawesi Selatan, seperti di Luwu memiliki nilai-nilai kepemimpinan yang dijadikan sebagai frame of reference dalam komunitasnya. Nilai-nilai tersebut masih relevan digunakan di zaman sekarang ini dan tidak kalah dengan paham modernisme. Nilai-nilai kepemimpinan yang dimiliki oleh masyarakat yang bersangkutan sangat terkait dengan sistem budaya yang dimiliki. Nilai-nilai itulah yang mempengaruhi dan membentuk keseluruhan sikap masyarakat terhadap satu orientasi, dan itulah yang muncul atau terpolakan ke atas permukaan dalam kehidupan sosial. Setiadi (2011:280) menyatakan bahwa sifat-sifat yang diisyaratkan pemimpin dalam setiap kehidupan sosial tidak sama, sebab di dalam setiap kehidupan masyarakat memiliki ketentuan-ketentuan sosial sendiri tentang bagaimana sifat pemimpin yang diharapkan memiliki kemampuan mengatasi persoalan-persoalan di dalam masyarakat sesuai dengan latar belakang budaya dan falsafah hidup masyarakatnya.

Wujud kearifan lokal dalam suatu komunitas akan mengalami pergeseran

$6 \quad$ Sifat yang harus dimiliki orang luwu yaitu sebagai berikut: 1. Melempukpi (memelihara kejujuran) 2. Makkeda tongeppi (selalu berkata benar) 3. Maegettengpi (teguh pada pendirian yang benar) 4. Malelengpi (mawas diri) 5. Masempopi (bermurah hati) 6. Manyameng kininnawapi (memelihara sikap peramah) 7. Waranipi (memelihara keberanian) 8. Temmapasilaingeppi (tidak pilih kasih). 
secara perlahan. Penelitian yang dilakukan Sartini terkait kearifan lokal di Bali menunjukkan perbedaan antara kearifan lokal sekarang dengan dulu dan bahkan yang akan datang. Hal tersebut menunjukkan bahwa kearifan lokal merupakan produk masyarakat yang di dalamnya terdapat nilai-nilai luhur yang telah terinternalisasi kepada penganutnya dari waktu ke waktu. Menyadari begitu pentingnya eksistensi nilai dalam penganggaran telah menggugah Mahzar (1983) memposisikannya sebagai elemen utama dalam lingkaran peradaban yang dibuatnya. Nilai kultur yang dimaksud tersebut adalah nilai-nilai kearifan lokal (local wisdom) seperti nilai-nilai yang terdapat dalam masyarakat yang sangat relevan digunakan sebagai pegangan dalam penyusunan anggaran.

Pembelajaran merupakan hasil dari interaksi sosial yang sarat dengan nilainilai sosial dan kearifan lokal. Atas dasar itu, maka penerapan pendidikan kearifan lokal Bugis haruslah mempertimbangkan lingkungan sosialnya di mana aktor mempraktikkan nilai-nilai kearifan lokal tersebut. Menurut Choi (1975), Alkafaji (1983), Hofstede (1987), Schreuder (1987), dan Perera (1989) bahwa pembelajaran kearifan lokal Bugis secara sosial diilhami oleh lingkungannya.

Kerajaan Luwu memiliki simbol pajung (raja) yang bermakna mengayomi rakyatnya dengan petuah, pasanre' ri adee' pattuppu ri sarae' (pola perilaku masyarakat luwu didasarkan pada konstitusi adat (ade') yang bertumpu pada ajaran agama Islam (syariat). Islam telah diterima lebih dahulu di kerajaan Luwu, kemudian di kerajaan Gowa-Tallo pada tahun yang sama, yakni tahun 1603. Penyebaran Islam dijalankan oleh kerajaan Gowa-Tallo kepada kerajaankerajaan yang ada di Sulawesi Selatan. Penyebaran ini dilakukan dengan dasar perjanjian yang pernah disepakati pada waktu yang lalu antara kerajaan Gowa dengan kerajaan-kerajaan yang lain. Isi kesepakatan tersebut di antaranya: bahwa barang siapa yang menemukan suatu jalan yang lebih baik, maka ia berjanji akan memberitahukan (tentang jalan yang lebih baik itu) kepada raja-raja sekutunya (Mattulada 1983; Abu Hamid 2005).

Penerimaan Islam di kerajaan Bugis tidak terlepas dari nilai filosofis yang dianut oleh mereka, khususnya konsep tentang ketauhidan, yakni Tuhan Yang Maha Esa atau ke-Esa-an Allah, sejalan dengan kepercayaan pra-Islam yang bersumber dari Ephos Galigo, yaitu Dewataseuae, Datu Palanro (Sang Pencipta), Aji Patoto (Sang Pengatur), La Puang e (Yang Dipertuan), dialah yang pertama, yang mengaruniakan rahmat dan menghukum orang yang bersalah (Kern 1991). Kepercayaan tentang adanya Tuhan Yang Maha Esa dapat dilihat dalam dialog antara orang macanang dengan Arung Matoae Wajo setelah mereka ditaklukkan dalam peperangan, di naskah Lontara Attorioloang ri Wajo, orang Macanang berkata sebagai berikut: "Kami Ata (budak) dan orang Wajo Puang-nya (Tuan), apapun yang dikehendaki oleh Wajo itulah yang kami ikuti" (Patmawati 2016:183-200).

Arung Matoae menjawab:

“Tuhan Yang Maha Esa menjadi saksi atas apa yang kamu katakan, pesankan kepada anak cucumu, yang tidak dibawa juga sampai mati tapi tak dimuat oleh tanah (harus pindah daerah)".

Nilai filosofi yang terdapat dalam lontara, baik yang sudah dipublikasikan 
maupun yang belum terpublikasi, membutuhkan kajian yang mendalam untuk mengetahui kebudayaan masa lampau, karena dalam naskah lontara tersebut tersimpan berbagai macam sumber kebudayaan. Lewat pengkajian lontara dapat diselamatkan dan dilestarikan warisan budaya masa lampau (Yunus 2020).

Gambaran kehidupan keagamaan di atas, terlihat jelas bagaimana kita menempatkan akhlak sebagai fondasi dasar dalam berinteraksi atau hidup di tengah kondisi masyarakat yang majemuk. Pengalaman telah membuktikan, bahwa dengan menggunakan pendekatan akhlak atau etika, sesuatu yang tadinya keras, kencang, akan menjadi lembut, halus, dan mencair. Apalagi jika pengejawantahan akhlak tersebut dirasa rasional atau dapat dicerna oleh akal, sehingga akan mengarahkan kepada rasa simpati dan empati manusia, yang menggerakkan emosional dengan bingkisan spiritual, sehingga semua aktivitas yang dilakukan diridhai Allah swt.

\section{Penutup}

Bagi Masyarakat Luwu nilai-nilai terdapat dalam Maccae ri Luwu, sesuati nilai berkaitan kehidupan sosial. Mengimpmentasikan nilai-nilai adalah suatu sikap yang bertujuan untuk membuat orang lain suka atau merasa nyaman dan aman. Beberapa sikap yang biasa diimplementasikan oleh masyarakat Luwu yang bersumber dari lontarak antara lain; ramah kepada siapapun, suka menolong, bersikap sesuai dengan norma dan tata kerama yang telah ditentukan-didasarkan pada pedoman dalam etika kehidupan sehari-hari yang disusun sangat pendek namun memiliki makna yang sangat bermanfaat, yaitu; tidak sombong dengan sifat ati maccinong (hati yang bersih) serta selalu berusaha untuk mengoreksi diri sendiri. Karena kedamaian merupakan landasan dan pedoman yang dianut dalam berperilaku bagi masyarakat Luwu. Ada berbagai sumber yang mengandung nilai-nilai kedamaian seperti Abbulo Sibatang. Kemudian persatuan bagaikan bulat beras, dimaknai sebagai suatu persatuan yang bersifat vertikal adalah persatuan antara raja atau pemimpin dengan rakyatnya, sehingga apa yang menjadi kebesaran dari sang raja, akan menjadi kekuatan bagi sang hamba. Tidak ada saling mencurigai antara raja dengan rakyatnya, rakyat tidak menginginkan kedudukan raja, demikian juga sang raja tidak ingin diperhambakan oleh rakyatnya. Tidak ada saling memarahi dan saling dendam. Hubungan baik antara raja atau pemimpin dengan rakyat berjalan sampai pada anak cucu. Kemudian persatuan bulat bagaikan buluh bambu, yakni antara raja atau pemimpin dengan rakyatnya bersatu dalam suka maupun duka. 


\section{Daftar Pustaka}

Abdullah, Hamid. 1985. Manusia Bugis Makassar: Suatu Tinjauan Historis terhadap Pola Tingkah laku dan Pandangan Hidup Manusia Bugis-Makassar, Jakarta: Inti Idayu Press.

Abidin, A. Zainal. 1999. Kapita Selekta Sejarah Sulawesi Selatan, Ujung Pandang: Hasanuddin University Press.

Choi, Frederick D.S. 1975. Multinational Challenges for Managerial Accountans. Journal of Contempory Business (Autumn):

Edson, Gary, ed. 2005. Museum Ethics, London and New York: Taylor and Francis e-Library.

Fadilah, Ali. 2000. Kedatuan Luwu, Makassar: Lembaga Penerbitan Universitas Hasanuddin atas Kerjasama dengan Institut Etnografi Indonesia.

Fauziah. 2001. "Analisis Nilai-Nilai Kehidupan Batara Guru dalam Naskah Mula Tau" dalam Laporan Penelitian Sejarah dan Nilai Tradisional Sulawesi Selatan, Makassar: BKSNT.

Gibson. 2009. Kekuasaan, Raja, Syeikh, dan Ambtenaar, Pengetahuan Simbolik dan Kekusaan Tradisional Makassar 1300-2000, Makassar: Ininnawa.

Hamid, Abu. 2005. Syekh Yusuf Seorang Ulama: Sufi dan Pejuang, Jakarta: Obor,

Hofstede, G., 1987. The Culture's Context of Accounting: In Berry E Cushing (ed). Accounting and Culture, Sarasota: American Accounting Association.

Ibrahim, Sulesana Anwar. 2003.Kumpulan Esai tentang Demokrasi dan Kearifan Lokal, Makassar: Lembaga Penerbitan Universitas Hasanuddin.

Iriani. 2011.Tari Pajaga Bone Balla Sebagai Cermin Budaya Luwu, Makassar: Dian Istana.

Kern, R.A., I Lagaligo. 1991. ter. La Side dan Sagimun MD (Yogyakarta: Gajah Mada University Press.

Kusuma, Andi Ima. 2006. “Sistem Perkawinan Adat Luwu yang Relevan dalam Transformasi Kebudayaan Nasional" dalam Iwan Sumantri (ed.), Kedatuan Luwu Persfektif Arkeologi, Sejarah dan Antropologi, edisi ke 2, T.t: Jendela Dunia.

Leirissa, R.Z. 1993. Sejarah Nasional Indonesia IV, Jakarta: Balai Pustaka,

Mahzar. 1983. Integralisme Bandung: Penerbit Pustaka Perpustakaan Salman ITB.

Marala, A. Karim Daeng. 1951. Demokrasi Sesudah Sawerigading Makassar: Departemen Pendidikan dan kebudayaan.

Mattulada. 1998. Sejarah Masyarakat dan kebudayaan Sulawesi Selatan, Ujungpandang: Hasanuddin University Press.

-------. 1995. Latoa: Suatu Lukisan Analisi Antropologi Politik Orang Bugis, Ujungpandang: Hasanuddin University Press.

--------. 1983. Islam di Sulawesi Selatan" dalam Agama dan Perubahan Sosial, ed. Taufik Abdullah, Jakarta: CV. Rajawali.

Mulyono, Hadi dan Abd Muthalib. 1979. Sejarah Kuno Sulawesi-Selatan, 
Ujungpandang: Suaka Peninggalan Sejarah dan Purbakala Sulawesi-Selatan. Parera, M.H.B. 1989.Towards a Framework to Analyze the Impact of Culture on Accounting. The International Journal of Accounting 24 (1).

Patmawati. 2016. Peranan Nilai Philosofi Bugis terhadap Proses Pengislaman Kerajaan Bugis Makassar di Sulawesi Selatan, Jurnal Khatulistiwa, Journal of Islamic Studies Volume 6 Nomor 2 September.

Pegeaud, Th. G. 1960.Java in the Fouteenth Century, A Study in Cultural History. Vol. III; The Hague: Martinus Nijhoff.

Rahman, Nurhayati. 2003. "Pendahuluan” dalam La Galigo Menelusuri Jejak Warisan Sastra Dunia. Makassar: Pusat Studi La Galigo Unhas.

Salle, Aminuddin, J Bostan Dg Maja, dan Supriadi Hamdat. 2010. Rekaman awal Kepemimpinan Elit Lokal Karaeng Galesong.

Schreuder, Hein. 1987. Accounting Research, Practice and Culture: A European Perspective, in Barry E. Cushing (ed). Accounting and Culture. Sarasota, FL: American Accounting Association:

Setiadi dkk. 2011. Pengantar Sosiologi, Jakarta: Kencana.

Sartini. 2004. Menggali Kearifan Lokal Nusantara: Sebuah Kajian Filsafat, Jurnal Filsafat, Agustus, Jilid 37, Nomor 2.

Sitanggang, Filasafat dan Etika Pemerintahan, Jakarta: Pustaka Sinar Harapan, 1998.

Slametmuljana, RB. 1967. Perundang-undangan Majapahit. Jakarta: Bharata.

Slamet Muljono. 1965. Menudju Poentjak Kemenangan Sedjarah Keradjaan Majapahit, Jakarta: Balai Pustaka,

Triyuwono, Iwan. 2000.Organisasi dan Akuntansi Syari'ah, Yogyakarta: LKiS.

Yamin, Muhammad. 1948. Gadjah Mada Pahlawan Poersatuan Noesantara. Jakarta: Balai Pustaka.

Yunus, Y., 2020. NILAI-NILAI KEARIFAN LOKAL DALAM PERIODE TOMANURUNG. Mimbar Agama Budaya, pp. 29-42. 